\title{
Vertical greening systems: contribution to thermal behaviour on the building envelope and environmental sustainability
}

\author{
K. Perini ${ }^{1} \&$ M. Ottelé ${ }^{2}$ \\ ${ }^{I}$ Department of Architectural Sciences, University of Genoa, Italy \\ ${ }^{2}$ Faculty of Civil Engineering and Geosciences, \\ Delft University of Technology, The Netherlands
}

\begin{abstract}
Contemporary architecture is increasingly focusing on vertical greening systems as a means to restore the environmental integrity of urban areas and sustainability. Despite the interest demonstrated by the European market and the international research on this topic, vertical greening systems are not yet fully accepted as an energy saving method for the built environment.

This paper provides a perspective on vertical greening systems with respect to the possible improvement of the building envelope efficiency in the field of environmental sustainability. The several systems available on the market have different characteristics (layers involved, plant species, maintenance needs, etc.), which influence the cooling potential and the insulation properties besides their aesthetic effect, functional aspects, and the environmental burden produced during the their life span. The analysis of the different characteristics, advantages and critical aspects of vertical greening systems considers the complexity of these systems and the potential improvement of building envelope efficiency brought by vertical gardens.
\end{abstract}

Keywords: green façade, living wall system, building envelope, thermal behaviour, energy saving, environmental sustainability.

\section{Introduction}

In the last few years the attention towards the environment seems to have become one of the primary objectives to follow. The ecological theories, 
developed from the seventies onwards, have contributed to the diffusion of a better awareness as far as our actions on a global level are concerned [1].

The integration of vegetation can play an important role, especially in dense urban areas with lack of green zones, becoming the scene of important environmental issues relative to pollution in the atmosphere with consequences on the physical wellbeing and comfort of the local inhabitants $[2,3]$. The many systems available on the market allow combining nature and built space to improve the environmental quality in urban areas. In general terms the main benefits connected to a green building envelope regard environmental practices, economics, and social aspects, as the greenhouse gases output reduction, climate change adaptation, air quality and indoor and outdoor comfort conditions improvement, urban wildlife (biodiversity), etc.; these benefits concern several fields, which are all related and operate at a range of scales, some only work if a large surface in the same area is greened and their benefits are only apparent at a neighbourhood or city scale; others operate directly on the building scale [3].

This paper provides a perspective on some vertical greening systems with respect to the possible improvement of the building envelope efficiency in the field of environmental sustainability. The several systems available on the market have different characteristics, which influence the cooling potential and the insulation properties besides their aesthetic effect, functional aspects, and the environmental burden produced during their life span.

\subsection{Definitions and characteristics}

Vertical green, also commonly referred to as "vertical garden", is a term which refers to all forms of vegetated wall surfaces [4] as with plants either rooted into the ground, in the wall itself or in modular panels attached to the façade. Vertical green can be classified as façade greening or living wall systems according to the growing method employed $[2,3]$.

Green façades use climbers attached directly to the building surface (a), as in traditional architecture, or supported by cables or trellis (b, fig. 1). Climbers planted on the base of the building provide a relatively inexpensive façade greening. Climbers, although, imply extra work in case of damages, and maintenance of the façade. When planning a green façade with this method it is important to consider that some climbing plants can grow 5 or 6 metres high, others around 10 metres and some species at least 25 metres [3].

A

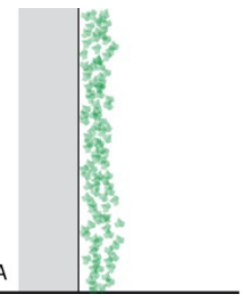

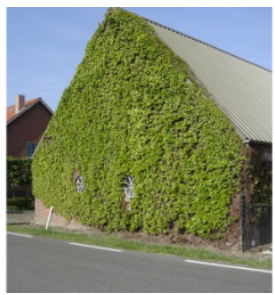

B

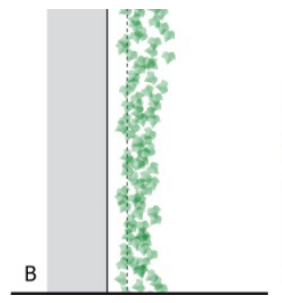

Figure 1: A: green façade based on climbers attached directly to the building surface; B: green façade based on climbers supported by cables. 
In a second case scenario, where an indirect greening system is applied, vegetation is supported by cables or meshes. In this occurrence many materials can be used as support for climbing plants as steel (coated steel, stainless steel, galvanized steel), different types of wood, plastic or aluminium. Each of the materials enumerated changes the aesthetical and functional properties due to different weight, profile thickness, durability, and cost $[5,6]$.

Living wall systems (LWS), which are also known as green walls and vertical gardens, are constructed from modular panels which contain soil or other artificial growing mediums, for example foam, felt, perlite and mineral wool. Panels require hydroponic cultures using balanced nutrient solutions to provide all or part of the plant's food and water requirements [3].

These systems usually employ evergreen plants as small shrubs which do not naturally grow vertically. Different kinds of living wall systems have been developed in the last few years. Each one has specific characteristics, starting from the growing medium. Two types of living wall systems with different principles of growing and planning are shown in fig. 2: the LWS based on plastic planter boxes (HDPE) is filled with potting soil (c), the LWS based on several felt layers (d), working as substrate and water proofing, supported by a PVC sheet.
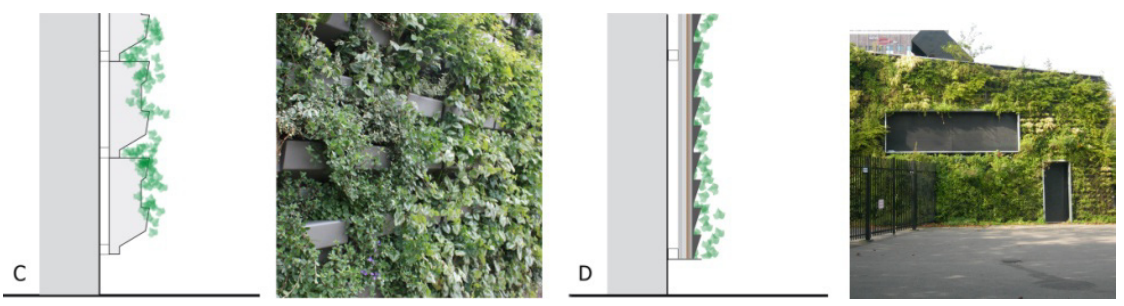

Figure 2: C: living wall system based on planter boxes; D: living wall system based on felt layers.

Living wall systems increase the variety of plants engaged as they don't make use exclusively of climbing plants and offer much more creative and aesthetical potential. From a functional point of view most of the living walls systems demand a more complex design compared to green façades as a greater number of variables must be considered, several layers are involved, there are more supporting materials, and control of water and nutrients must be carried out. Living wall systems in fact are often very expensive, energy consuming and difficult to maintain $[5,7]$.

\section{Improving the building envelope efficiency with vertical greening systems}

The use of horizontal and vertical green has an important impact on the thermal performance of buildings and on the effect of the urban environment as well; both in summer and winter. Plants are functioning as a solar filter and prevent 
the adsorption of heat radiation of building materials extensively. Applying green façades is not a new concept; however it has not been fully approved as an energy saving method for the built environment.

Dense urban areas have a lot of paved surfaces and surfaces with a low albedo (factor: white 1; black 0) and a lack of natural vegetation with a higher albedo 0.8. This result in warming up of building materials in combination with less evapotranspiration to a phenomenon called urban heat island effect. Besides fine particle (PMx) movement [8] caused by turbulences, a low humidity of the air will appear. Introducing vegetation back in our cities is a possibility to alter the microclimate in street canyons and the total built environment. Outer surfaces of buildings offer a great and unused amount of space for re-introducing vegetation in our cities. Green roofs and green façades are possibilities to fulfil this opportunity.

By constructing green façades and green roofs great quantities of solar radiation will be adsorbed for the growth of plants and their biological functions. Substantial amounts of radiation are used for photosynthesis, transpiration, evaporation and respiration [9].

Field measurements on a with vegetation covered wall and a bare wall by Bartfelder and Köhler [10] show a temperature reduction at the green façade in a range of $2-6^{\circ} \mathrm{C}$ compared with the bare wall. Holm [11] shows with field measurements and his DEROB computer model the thermal improvement potential of leaf covered walls. In addition, Eumorfopoulou and Kontoleon [12] reported the temperature cooling potential of plant covered walls in a Mediterranean climate; the effect was up to $10.8^{\circ} \mathrm{C}$. Another recent study by Wong et al. [13] on a free standing wall in Hortpark (Singapore) with vertical greening types shows a maximum reduction of $11.6^{\circ} \mathrm{C}$.

Case studies demonstrate that green façades and living wall systems have different characteristics which help to reduce temperatures and positively affect buildings' insulating properties due to the thickness of the foliage. This foliage layer creates a stagnant air layer and shades the façade and due to water content, material properties, and possible air cavities formed between the different layers of leaves [14].

The thermal transmittance and thus insulation properties of a building are affected by many factors such as the wind velocity that hits the surface of the building [15]. A green layer can enhance the thermal properties of a façade and provide protection from heavy wind as shown by a study conducted by Perini et al. [14]. An extra stagnant air layer can be created inside the foliage so that when the wind speed outside is the same as inside Rexterior can be equalized to Rinterior. In this way the building's thermal resistance increases by 0.09 $\mathrm{m}^{2} \cdot \mathrm{K} \cdot \mathrm{W}^{-1}$. These results refer to the wind speed measured on a façade covered by a well grown direct greening system (a, fig. 1) and a living wall system based on planter boxes (c, fig. 2); in the case of living wall systems the insulation properties change according to the materials employed. For both green façades and living wall systems these results imply potential energy savings for building envelopes in warmer and colder climates [14]. 


\subsection{Quantifying thermal behaviour of vertical greening concepts}

An experimental approach was conducted in order to classify the thermal benefits of green façades or plant covered cladding systems under boundary conditions [16]. The obtained data can be used in engineering tools for architects, building owners, etc. and this all to calculate with vertical green as an "extra insulation" layer. In research work done by Eumorfopoulou and Aravantinos in 1998 [17], they concluded that a planted roof contributes to the thermal protection of a building but that it cannot replace the thermal insulation layer. From a scientific point of view it is interesting if this is also valid for green façades.

In order to discover if this hypothesis is true a procedure was made to measure steady-state (stationary condition) heat transfer through an insulated (mineral wool) cavity wall with (attached) different vertical greening systems. In total there are two measurements performed with Hedera helix (direct and indirect to the wall) and four measurements are carried out with living wall systems (based on felt layers, planter boxes, mineral wool and foam substrate). In this article only Hedera helix directly and indirectly to the wall and two living wall systems based on felt layers and planter boxes are analysed.

The climate chamber used in this experiment [16] was designed and constructed according to NEN-EN 1934 [18]. The standard requires a "hot" chamber on one side of the tested specimen and a heat sink in the form of a "cold" chamber in which environmental conditions are imposed. The outside and inside climate chambers have the same dimensions and are as follows (fig. 3): length $\mathrm{L}=1.10 \mathrm{~m}$, width $\mathrm{w}=1.40 \mathrm{~m}$, height $\mathrm{H}=1.40 \mathrm{~m}$.

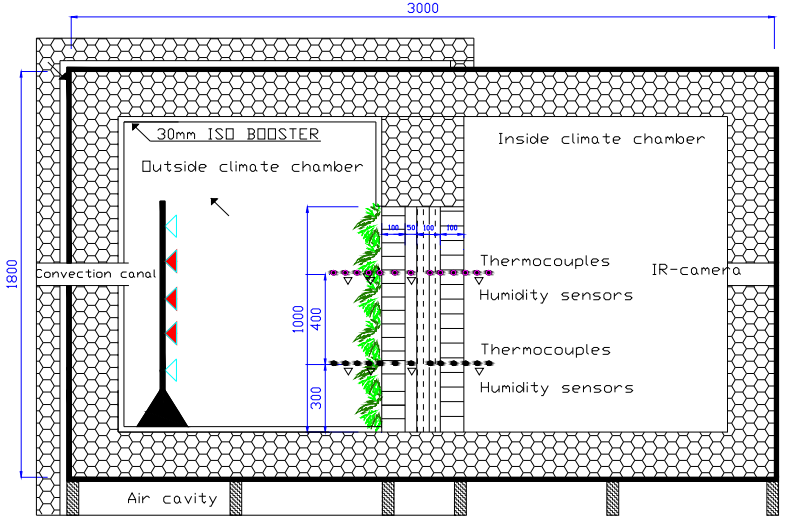

Figure 3: Cross section of the designed box and the positions of the thermocouples used (dimensions in $\mathrm{mm}$ ).

\subsubsection{Direct and indirect façade greening}

For the direct and indirect greening principle (fig. 1) it is found that for the summer condition the average temperature of the wall surface is lower compared to the bare wall. The difference of temperature for the systems is reaching $1.7^{\circ} \mathrm{C}$ 
and $1.9^{\circ} \mathrm{C}$ respectively after 8 hours of heating. The insulation material inside the bare wall moderates the prevailing temperature difference between the outside and inside climate chamber, resulting in no temperature difference for the inside climate chamber. The winter measurement after 72 hours shows that the wall surface covered directly with Hedera helix is warmer compared to the bare wall, with a temperature difference of $1.7^{\circ} \mathrm{C}$. The air temperature of the inside climate chamber is lowered with $0.7^{\circ} \mathrm{C}$ in the case of the bare wall, which means that the vegetation layer slows down the rate of heat flow through the façade, resulting in a improved R-value of the system. In the case of the indirect facade greening system the same trend was found; a temperature difference of $1.9^{\circ} \mathrm{C}$. compared with the bare wall was found the interior air temperature is lowered with $1^{\circ} \mathrm{C}$ in the case of the bare wall.
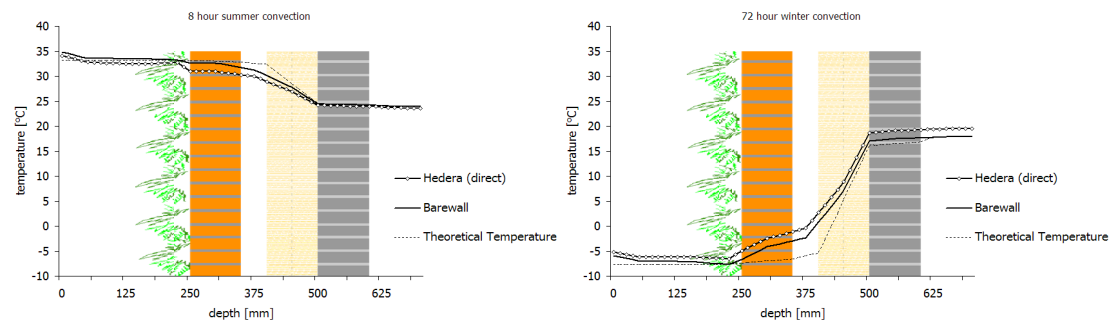

Figure 4: (Left) Temperature development after 8 hours of heating $\left(35^{\circ} \mathrm{C}\right)$, for a bare wall compared with a direct greening principle; theoretical line is based on the prevailing temperature to predict a steady state situation for the bare wall. (Right) Temperature development after 72 hours of cooling, for a bare wall compared with a direct greening principle.
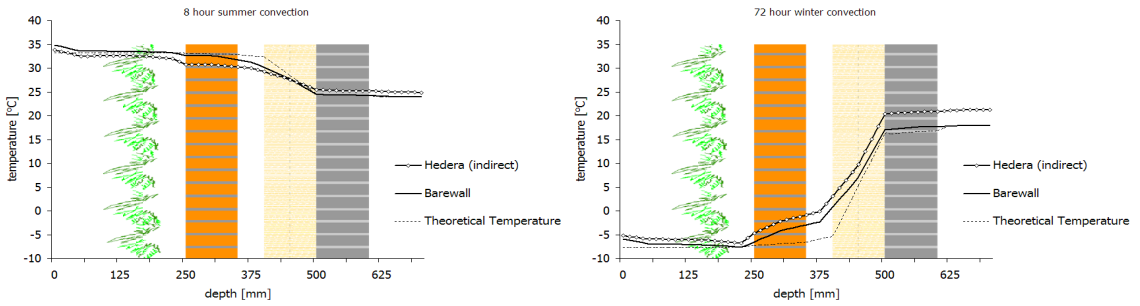

Figure 5: (Left) Temperature development after 8 hours of heating $\left(35^{\circ} \mathrm{C}\right)$, for a bare wall compared with an indirect greening principle; theoretical line is based on the prevailing temperature to predict a steady state situation for the bare wall. (Right) Temperature development after 72 hours of cooling, for a bare wall compared with an indirect greening principle. 


\subsubsection{Living wall system based on felt layers}

For the living wall system based on felt layers (fig. 2,d), it was found that for the summer condition the average temperature of the wall surface is lower compared to the bare wall, with a temperature difference reaching $7.2^{\circ} \mathrm{C}$ after 8 hours of heating. This fits well with the other living wall concepts compared to the direct and indirect greening system where lower temperature differences were found. The air temperature difference between the exterior chamber and the air temperature of the extra created air cavity between LWS and façade was $10.3^{\circ} \mathrm{C}$. During the experiments, the same trend was found for the insulation material (inside the cavity wall), it moderates the prevailing temperature difference substantially between the exterior and interior climate chamber, resulting in no temperature difference for the interior climate chamber. Again high humidity levels were found during the measurement inside the exterior climate chamber. The winter measurement shows a surface temperature difference between the bare wall and the wall covered with felt layers of $10.4^{\circ} \mathrm{C}$ and a difference of $4.3^{\circ} \mathrm{C}$ between the exterior air temperature and the air temperature inside the extra created cavity between living wall and façade. The interior chamber air temperature difference between the bare wall and the covered wall after 72 hours came up $2^{\circ} \mathrm{C}$, resulting again in an improved R-value of the system.
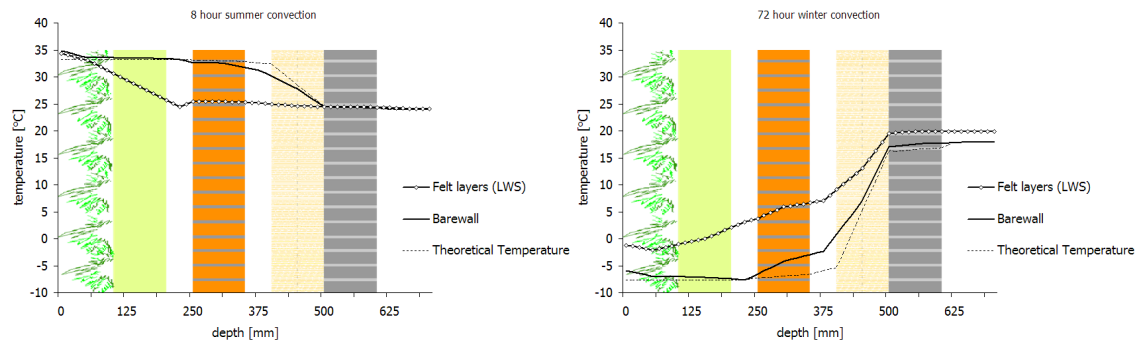

Figure 6: (Left)Temperature development after 8 hours of heating $\left(35^{\circ} \mathrm{C}\right)$, for a bare wall compared with a living wall system based on felt layers; theoretical line is based on the prevailing temperature to predict a steady state situation for the bare wall. (Right) Temperature development after 72 hours of cooling, for a bare wall compared with a living wall system based on felt layers.

\subsubsection{Living wall system based on planter boxes}

For the planter boxes system (fig. 2,c), it was found that for the summer condition the average temperature of the wall surface is lower compared to the bare wall, with a temperature difference reaching $5.8^{\circ} \mathrm{C}$ after 8 hours of heating. This is a substantial difference with the direct and indirect greening system. Also, for the living wall system based on planter boxes it was noticed that the insulation material inside the bare wall moderates the prevailing temperature difference between the outside and inside climate chamber, resulting in no temperature difference for the interior climate chamber. It is noteworthy to mention that the temperature difference between the air of the exterior chamber 
and the temperature of the extra created air cavity between LWS and façade is $8.6^{\circ} \mathrm{C}$. It was noticed that the humidity inside the exterior climate chamber lays between $85 \%$ and $100 \%$ for the measurement; this is probably related to the moisture content of the substrates used for the living wall systems.

The winter measurement show after 72 hours a temperature difference between the surface of the bare wall and the wall covered with planter boxes of $10.6^{\circ} \mathrm{C}$, with a temperature difference between the exterior air temperature and the extra created cavity of $5.5^{\circ} \mathrm{C}$. The interior air temperature difference after the measurement came up $2.1^{\circ} \mathrm{C}$ and thus resulting in an improved R-value of the system.
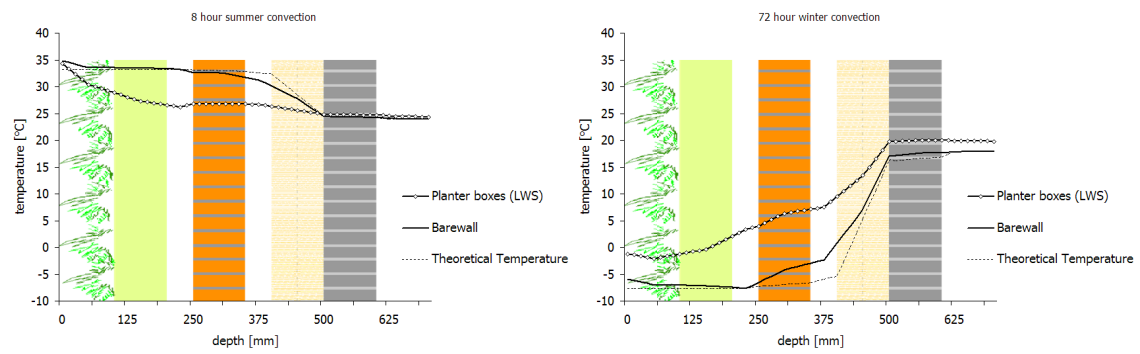

Figure 7: (Left) Temperature development after 8 hours of heating $\left(35^{\circ} \mathrm{C}\right)$, for a bare wall compared with a living wall system based on planter boxes; theoretical line is based on the prevailing temperature to predict a steady state situation for the bare wall. (Right) Temperature development after 72 hours of cooling, for a bare wall compared with a living wall system based on planter boxes.

\section{Vertical greening systems and sustainability}

Greening systems cause positive environmental and microclimatic effects but it has to be demonstrated if all of these systems are sustainable, due to the materials used, maintenance, nutrients and water needed [5].

Sustainability can be defined as a general property of a material or a product that indicates whether and to what extent the prevailing requirements are met in specific application. These requirements, which relate to air, water and soil loading, have influences on well being and health of living creatures, the use of raw materials and energy. These have also consequences for the landscape, the creation of waste and the occurrence of nuisance to surrounding environment [19].

A life cycle analysis is effective to evaluate the sustainability of a building considering the integral balance between the environmental load and possible benefits. A study conducted by Ottelé et al. [5] regarding a life cycle analysis of four greening systems shows the environmental burden profile in relation with the energy savings for air conditioning and heating (according with table 1). This research takes into account an estimation of the micro-scale benefits of greening systems in a Mediterranean and a temperate climate. The four greening systems 
analysed in this life cycle analysis are: a direct greening system (a, fig. 1), an indirect greening system (b, fig. 1), a living wall system based on planter boxes (c, fig. 2) and a living wall system based on felt layers (d, fig. 2).

Table 1: Energy saving for heating, energy saving for cooling and temperature decrease for Mediterranean and temperate climate [5] based on Alexandri and Jones [20] and Perini et al. [14].

\begin{tabular}{cccc}
\hline \multirow{2}{*}{ Greening system } & Benefit & $\begin{array}{c}\text { Mediterranean } \\
\text { climate }\end{array}$ & $\begin{array}{c}\text { Temperate } \\
\text { climate }\end{array}$ \\
\hline Direct green & energy saving for heating & $1,2 \%$ & $1,2 \%$ \\
& temperature decrease & $4,5^{\circ} \mathrm{C}$ & $2,6^{\circ} \mathrm{C}$ \\
& energy saving for cooling & $43 \%$ & --- \\
\hline Indirect green & energy saving for heating & $1,2 \%$ & $1,2 \%$ \\
& temperature decrease & $4,5^{\circ} \mathrm{C}$ & $2,6^{\circ} \mathrm{C}$ \\
\hline LWS planter & energy saving for cooling & $43 \%$ & --- \\
\hline bWes & energy saving for heating & $6,3 \%$ & $6,3 \%$ \\
& temperature decrease & $4,5{ }^{\circ} \mathrm{C}$ & $2,6^{\circ} \mathrm{C}$ \\
& energy saving for cooling & $43 \%$ & --- \\
\hline \multirow{2}{*}{ LWS felt layers } & energy saving for heating & $4 \%$ & $4 \%$ \\
& temperature decrease & $4,5^{\circ} \mathrm{C}$ & $2,6^{\circ} \mathrm{C}$ \\
& energy saving for cooling & $43 \%$ & --- \\
\hline
\end{tabular}

As shown in fig. 8, the energy benefits provided by the greening options make a noteworthy impact in the life cycle analysis (LCA); in a Mediterranean climate the benefits calculated are roughly two times higher than for temperate climates. This is due to the energy savings related to the cooling potential. This life cycle analysis by Ottelé et al. [5] proves that:

- Direct greening systems have a very small influence on the total environmental burden. Thus this type of greening, without any additional material involved, is always a sustainable choice for the examined cases.

- Indirect greening systems analysed based on a stainless steel supporting system have a high influence on the total environmental burden.

- Living wall systems based on planter boxes do not have a major environmental footprint due to the materials involved, since the materials affect positively the thermal resistance of the system.

- Living wall systems based on felt layers have a high environmental burden due to the durability aspect and the materials used.

This is a growing field of study which has developed rapidly especially in the last three to four years so that various living wall systems and greening systems with different materials and characteristics are available [21]. 


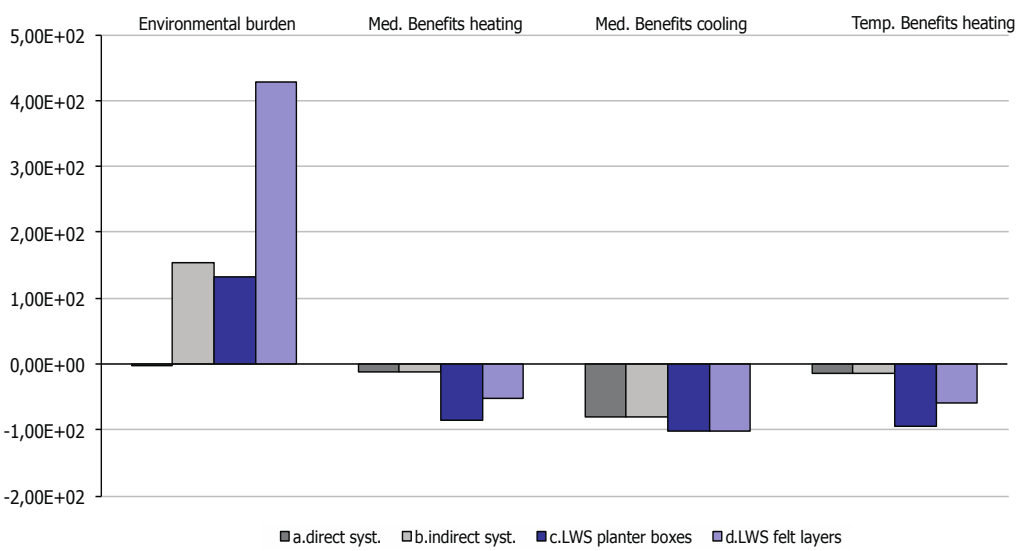

Figure 8: Total environmental burden for four greening systems (supporting systems + vegetation), benefits for heating and cooling for Mediterranean climate and benefits for heating for temperate climate according to Ottelé et al. [5].

Many types of materials such as different types of wood, plastic, aluminium and steel used to build indirect greening systems can be a support for climbing plants instead of stainless steel mesh. These materials can cause an environmental burden of the system roughly 10 times lower than the stainless steel mesh [5].

Greening the building envelope, can be thus a sustainable option for new constructions and retrofitting when using materials with a low influence on the environmental profile although not all benefits are yet quantifiable [5].

\section{Conclusions}

Green façades and living walls systems can improve the (local) environment in cities. They offer more surfaces with vegetation and, at the same time, contribute to the improvement of the thermal performance of buildings. Characteristics, components, and materials of vertical greening systems can have an influence on the environmental burden and environmental benefits, etc., as discussed throughout the article. The thickness of the air cavity (green layer-façade) and the foliage affects the thermal resistance beneficial, as well as other material layers involved in the case of living wall systems. Material choice and durability aspects are important (environmental impact) when the energy demand of a building can be reduced or when the multi-functionality of the construction due to the integration of vegetation can be increased. Therefore a green building envelope strategy is very important for a sustainable approach.

Measurements from the designed climate chamber (hotbox) show the effect of different vertical greening systems on the temperature gradient through the greened insulated brick wall. For all the systems studied temperature differences 
were found between a bare and a greened façade. Nearly no temperature differences were measured for the interior climate after 8 hours of heating, the inhibitory effect of the insulation material used inside the bare wall was clearly noticeable for the direct, indirect and investigated living wall systems (based on felt layers and planter boxes). It was also found that the temperature gradient through living wall systems show an inhibitory effect, which results in significantly lower temperatures (up to $10^{\circ} \mathrm{C}$ ) of the exterior masonry. Due to these lower temperatures less heat is accumulated in the building envelope, which contributes mostly to the urban heat island effect (outdoor climate). From the results, it can be concluded that there is especially a positive effect of living wall systems on the thermal behaviour of buildings. However for a sustainable approach the microclimatic and environmental benefits obtainable have to be related to the environmental burden produced during the whole life span of a vertical greening system.

\section{References}

[1] Bateson G., 1977. Verso un'ecologia della mente (prima ed. Chandler Publishing company, 1972), Adelphi, • Milano.

[2] Köhler, M., 2008. Green façades - a view back and some visions, Urban Ecosyst 2008 vol. 11, pp. 423-436.

[3] Dunnett, N., Kingsbury, N., 2008. Planting green roofs and living walls.

[4] www.greenroofs.org

[5] Ottelé, M, Perini, K., Fraaij, A.L.A., Haas, E.M. and Raiteri, R., 2011. Comparative life cycle for green facades and living walls. Energy and Buildings, 43(12), 3419-3429.

[6] Perini, K., 2012. L'integrazione di vegetazione in architettura. Metodi e strumenti innovativi. The integration of vegetation in architecture. Innovative methods and tools. Dissertation University of Genoa, ISBN 9788890692505.

[7] Perini K., Ottelé M., Haas E.M., Raiteri R., 2011. Greening the building envelope, façade greening and living wall systems, Open Journal of Ecology (2011), Vol.1, No.1, 1-8 (2011) doi:10.4236/oje.2011.11001.

[8] Minke, G.,Witter, G., 1982. Häuser mit grünen pelz. Ein handbuch zur hausbegrünung.

[9] Krusche, P., Krusche, M., Althaus, D., Gabriel, I., 1982. Ökologisches bauen. Herausgegeben vom umweltbundesamt, Bauverlag.

[10] Bartfelder, F., Köhler, M., 1987. Experimentelle Untersuchungen zur Funktion von Fassadenbegrunungen. Förderungsprogramm der Freien Universitat Berlin fur junge Wissenschaftler 3. Ausschreibung.

[11] Holm, D., 1989. Thermal improvement by means of leaf cover on external walls - A simulation model. Energy and Buildings, 14 (1989) 19-30.

[12] Eumorfopoulou, E.A., Kontoleon, K.J., 2009. Experimental approach to the contribution of plant covered walls to the thermal behaviour of building envelopes. Building and Environment 44 (2009) 1024-1038. 
[13] Wong N.H., et al., 2009. Thermal evaluation of vertical greenery systems for building walls, Building and Environment, doi:10.1016 /j.buildenv.2009.08.005.

[14] Perini, K., Ottelé, M., A.L.A. Fraaij, Haas, E.M., Raiteri, R., 2011. Vertical green systems and their effect on air flow and temperature near the façade. Building and Environment, 2011. doi: 10.1016/j.buildenv.2011.05.009.

[15] European Standard NEN-EN ISO 6946 Building components and building elements - Thermal resistance and thermal transmittance.

[16] Ottelé, M., 2011. The Green Building Envelope. Dissertation Delft University of Technology. ISBN 978-90-9026217-8.

[17] Eumorfopoulou, E.A., Aravantinos, D., 1998. The contribution of a planted roof to the thermal protection of buildings in Greece, Energy and Buildings 27 (1) (1998), pp. 29-36.

[18] European Standard NEN-EN 1934 Thermal performance of buildings Determination of thermal resistance by hot box method using heat flow meter.

[19] Hendriks, C.F., Bijen, J.MJ.M, Felix, F., Fraaij, A.L.A., Janse, H., de Munck, E.D., Reintjes, R.C., Schutte-Postma, E.T., Stroeven, P., Vogtlander, J.G., van der Wegen, G.J.L., 2000. Durable and sustainable construction materials. ISBN 90-75-365-30-6.

[20] Alexandri, E., Jones, P., 2008. Temperature decrease in a urban canyon due to green walls and green roofs in diverse climates, Building and Environment 43 (2008) 480-493. 681.

[21] Corrado M., 2010. Il verde verticale, Sistemi Editoriali, Napoli, Italy 